\title{
Erratum to application of a two-dimensional code video in neurosurgery device manipulation training for growing nurses in operating room
}

\author{
Editorial Office
}

Gland Surgery

Correspondence to: Editorial Office. Gland Surgery. Email: editor@glandsurgery.org.

Submitted Jan 19, 2022. Accepted for publication Feb 09, 2022.

doi: $10.21037 / \mathrm{gs}-2022-01$

View this article at: https://dx.doi.org/10.21037/gs-2022-01

Erratum to: Gland Surg 2021;10:3233-40

In the December 2021 issue of Gland Surgery, the paper "Application of a two-dimensional code video in neurosurgery device manipulation training for growing nurses in operating room" (doi: 10.21037/gs-21-129) by Dr. Liu et al. (1) was published with some errors in the authorship by missing the marks of the co-first authors. The authors Min Liu and Xuan Li should be the co-first authors. Therefore, the author list of this article should be corrected as below.

Min Liü, Xuan Li", Fei Yin, Chen Yi

Department of Operation, The Central Hospital of Wuhan \& Affiliated Hospital of Tongji Medical College of Huazhong University of Science and Technology, Wuhan, China

"These authors contributed equally to this work.

Correspondence to: Fei Yin; Chen Yi. Department of Operation, The Central Hospital of Wuhan \& Affiliated Hospital of Tongji Medical College of Huazhong University of Science and Technology, Wuhan 430000, China. Email: 11096257@qq.com; 28225369@qq.com.

The authors regret the error and all inconveniences caused.

Click here to view the updated version of the article.

Open Access Statement: This is an Open Access article distributed in accordance with the Creative Commons AttributionNonCommercial-NoDerivs 4.0 International License (CC BY-NC-ND 4.0), which permits the non-commercial replication and distribution of the article with the strict proviso that no changes or edits are made and the original work is properly cited (including links to both the formal publication through the relevant DOI and the license). See: https://creativecommons.org/licenses/by-nc$\mathrm{nd} / 4.0 /$. 


\section{References}

1. Liu M, Li X, Yin F, et al. Application of a two-dimensional code video in neurosurgery device manipulation training for growing nurses in operating room. Gland Surg 2021;10:3233-40.

Cite this article as: Editorial Office. Erratum to application of a two-dimensional code video in neurosurgery device manipulation training for growing nurses in operating room.

Gland Surg 2022;11(2):511-512. doi: 10.21037/gs-2022-01 